\title{
Analisis komparasi implementasi Steganografi White-Space dan White-Space Modified pada Artikel Terenkripsi AES dalam HTML5
}

\author{
${ }^{1}$ Rudy Herteno, ${ }^{2}$ Dodon T. Nugrahadi, ${ }^{3}$ Muhammad Sholih 'Afif \\ ${ }^{4}$ M. Reza Faisal, ${ }^{5}$ Friska Abadi \\ 1,2,3,4,5 Jurusan Ilmu Komputer Universitas Lambung Mangkurat \\ Jalan Jl. Brigjen H. Hasan Basri, Kayu Tangi, Banjarmasin \\ e-mail : ${ }^{1}$ rudy.herteno@ulm.ac.id, ${ }^{2}$ dodonturianto@ulm.ac.id, ${ }^{3}$ afifsholihm@gmail.com, ${ }^{4}$ reza.faisal@ulm.ac.id, \\ ${ }^{5}$ friska.abadi@ulm.ac.id
}

\begin{abstract}
The level of internet usage continues to increase until now. information exchange requires security that cannot be predicted by others. one technique for securing information is steganography. Steganography techniques are the science and art of hiding information. This technique can hide the content of information in media that cannot be guessed by ordinary people, so as not to arouse suspicion of the people who see it. One of the media that can implement the white-space modified steganography method is HTML pages. in addition, AES (Advanced Encryption Standard) is a lighter encryption security algorithm compared to other algorithms. In this study, plain text that has been encrypted into cipher text is then inserted with white-space and white-space modification steganography techniques. Data changes have occurred but only less than 1 percent. In experiments that have been implemented on Google Chrome and Mozilla Firefox are the same except in Internet Explorer, which changes the data slightly larger. The implementation of AES encryption and stegano white-space original, has $100 \%$ success but the $80 \%$ decryption process is successful, but the decryption results contain additional binaries. This happen because the use of tabulation (tabs) instead of spaces in HTML5 articles, and this is often found in HTML articles. while the implementation of AES encryption and stegano whitespace modified, has a success of $100 \%$ and the decryption process of $90 \%$ succeeded without any changes. 1 article failed because the number of articles is too small compared to the amount of space provided. The conclusion that implementation of AES encryption and white-space modified is more appropriate to be implemented in HTML5 articles, and than the use of tabulation and the number of characters also consequences on the implementation.
\end{abstract}

Keywords: Information, Steganography, White-space modified, Security, AES, Web Browser

\section{[1] PENDAhuluan}

Pengembangan metode atau teknik yang dapat menjamin keamanan suatu informasi terus berlanjut. Salah satu teknik yang dapat mengamankan suatu informasi adalah steganografi. Teknik steganografi merupakan ilmu pengetahuan dan seni dalam menyembunyikan informasi. Teknik ini dapat menyembunyikan suatu informasi ke dalam suatu media yang tidak dapat diduga oleh orang biasa sehingga tidak menimbulkan kecurigaan dari orang yang melihatnya. Beberapa penelitian telah menerapkan teknik steganografi pada beberapa media, contohnya seperti pada format gambar, format suara dan format lain. Ada beberapa metode penyembunyian pesan, salah satunya adalah metode white-space[1].

Informasi dapat disembunyikan dalam dokumen web dengan metode white-space, menyembunyikan data dalam dokumen web kurang mencurigakan daripada media lain karena halaman web HTML sekarang merupakan bagian dari rutinitas berinternet setiap orang, serta halaman HTML berisi sejumlah tag, atribut dan elemen lainnya, yang dapat menyembunyikan data. Sejak awal ditemukannya HTML pada tahun 1990, HTML terus dikembangkan sampai saat ini dan versi terbaru yaitu HTML5. HTML5 memiliki struktur elemen baru bukan hanya tag dan div tradisional untuk membuat template halaman, hasil akhirnya adalah kode yang lebih baik dan teratur [3].

Keamanan menjadi faktor penting dalam proses pengiriman informasi melalui jaringan internet. Jika hal tersebut diabaikan, maka suatu informasi dapat dengan mudah dimanfaatkan oleh pihak-pihak yang tidak memiliki otoritas. Jika informasi tersebut digunakan untuk tujuan yang tidak semestinya, maka tentu saja hal ini dapat merugikan baik pengirim maupun penerima informasi. Untuk mengamankan informasi tersebut maka 
perlu adanya enkripsi pesan. Mahajan (2013) menjelaskan bahwa algoritma AES lebih baik dibandingkan algoritma DES ataupun RSA, waktu yang diperlukan untuk enkripsi dan dekripsi pun lebih sedikit [4].

Tahapan dalam penelitian ini diawali dengan melakukan enkripsi pesan memakai algoritma AES (Advanced Encryption Standard), kemudian disembunyikan ke dalam kode HTML5 dengan menggunakan teknik steganografi white-space dan white-space modified. Pengimplementasian penelitian ini dilakukan pada 3 web browser yang paling sering dipakai menurut survei pada tahun 2016 yang telah dilakukan oleh Asosiasi Penyelenggara Jasa Internet Indonesia (APJII) yaitu Google Chrome, Mozila Firefox dan Internet Explorer untuk melihat efek dari pengembangan tag otomatis yang dilakukan oleh browser tersebut terhadap metode white-space dan white-space modified modified, kemudian dilakukan pengamatan untuk mengetahui perubahan besaran data yang terjadi setelah kedua metode tersebut diterapkan [2].

\section{[2] STUDI LITERATUR}

\subsection{Algoritma Enkripsi Advanced Encryption Standart (AES)}

Algoritma Advanced Encryption Standard (AES) tidak hanya untuk keamanan tetapi juga untuk kecepatan tinggi. Implementasi perangkat keras dan perangkat lunak masih lebih cepat. Standar enkripsi baru direkomendasikan oleh NIST untuk menggantikan DES. Encrypts data blok 128 bit dalam 10, 12 dan 14 putaran tergantung pada ukuran kunci. Hal ini dapat diimplementasikan pada berbagai platform khusus pada perangkat kecil. Ini diuji secara hati-hati untuk banyak aplikasi keamanan[8].

Langkah-langkah ini digunakan untuk mengenkripsi blok 128-bit
a. Rangkaian kunci bulat dari kunci sandi
b. Inisialisasi pernyataan array dan tambahkan kunci putaran awal ke susunan pernyataan awal
c. Lakukan putaran $=1$ sampai 9 dan Jalankan putaran biasa
d. Lakukan putaran final
e. Menyesuaikan cipher text chunk output dari putaran final akhir [8].

\subsection{Metode White-Space}

Berbeda dengan kontainer multimedia yang bisa dimanipulasi pada tingkat biner, file yang dibuat dengan cara pemrograman web tidak mengizinkan manipulasi jenis ini. Karena kode HTML tidak sensitif terhadap " white-space ", maka dapat digunakan untuk menyembunyikan informasi memungkinkan terwujudnya saluran tersembunyi untuk transmisi data. Maka Metode steganografi teks bisa digunakan, yaitu satu dari cabang dasar steganografi, metode white-space.

Penyisipan informasi teks di dalam white-space dari kode HTML yang digunakan algoritma berikut ini :

a. Teks yang terbongkar diubah menjadi format biner.

b. Semua karakter kode HTML sedang diperiksa untuk menemukan " white-space " (spasi atau tab).

c. Karakter spasi digunakan untuk nilai 0, dan karakter tab untuk 1. Setelah menyematkannya dipindahkan ke item berikutnya dari informasi untuk penyematan.

d. Item 2 dan 3 diulang sampai penyisipan seluruh pesan atau sampai akhir kontestan.

e. Salah satu indikator kunci dalam menilai keefektifan metode steganografi dan algoritma adalah efektivitas penyisipan

$$
\mathrm{E}_{\mathrm{e}}=\mathrm{V}_{\max } / \mathrm{V}_{\mathrm{k}}
$$

dimana Vmax adalah jumlah maksimum informasi tersembunyi, dan Vk adalah volume wadah [1].

\subsection{Metode White-Space Modified}

Untuk meningkatkan efisiensi penyisipan diperlukan peningkatan jumlah posisi yang dapat menyematkan informasi tersembunyi. Metode yang diusulkan lagi berdasarkan pada fakta bahwa kode HTML tidak peka terhadap "white-space". Dengan itu selama embedding tambahan embedding karakter (spasi atau 
tab) digunakan sebelum karakter "<" dari tag HTML dan yang sama digunakan setelah karakter ">". Penyematan ini tidak memengaruhi visualisasi melalui peramban dan memungkinkan untuk meningkatkan kapasitas penampung secara signifikan.

Algoritma White-Space Modified sebagai berikut:

a. Teks diubah menjadi format biner.

b. Semua karakter kode HTML sedang diperiksa untuk menemukan " white-space " (spasi atau tab) atau karakter "<" dan ">".

c. Elemen dari text tak tertutup saat ini disertakan, yaitu karakter spasi dianggap nol, dan karakter tab dianggap 1.

d. Item 2 dan 3 diulang hingga embedding seluruh pesan atau hingga akhir penampung [1].

\section{[3] METODOLOGI PENELITIAN}

Pada tahap ini dilakukan proses pengembangan perangkat lunak sebagai purwarupa terhadap teknik enkripsi dan steganografi yang digunakan. Berikut ini adalah langkah-langkah pengembangan perangkat lunak secara umum proses metode Waterfall :

a. Analisa kebutuhan. Pada tahapan ini yang dilakukan adalah mengumpulkan informasi tentang yang berkaitan dengan perangkat lunak yang akan dirancang. Disamping itu juga untuk menentukan fitur-fitur yang digunakan ke dalam perangkat lunak tersebut. Selain iti studi pustaka dilakukan dengan cara mempelajari dan mengumpulan berbagai literature dari berbagai media seperti internet berupa jurnal atau dari penelitian yang dilakukan sebelumnya yang berhubungan dengan penelitian yang sedang dilakukan.

b. Desain perangkat lunak. Perancangan akan dilakukan setelah didapat hasil analisis tahapan sebelumnya. Tujuan dari perancangan ini adalah untuk kesesuaian gambaran dari perangkat lunak, cara kerja perangkat lunak dan antarmuka sebagai prototipe implementasi metode enkripsi AES, white-space standar dan whitespace modified. Berdasarkan data yang telah didapatkan, kemudian peneliti merancang terdapat fakta dan aturan berdasarkan data yang telah diperoleh.

c. Penulisan kode program. Menulis kode program dengan bahasa php dan html dalam mengimpelentasikan metode enkripsi AES dengan white-space standar dan white-space modified, penggunaan library AES dan ckeditor juga dibutuhkan untuk mendukung terbentuknya program yang baik.

d. Pengujian program. Dilakukan dengan ekperimental dengan pengujian menginputkan 10 artikel berbeda yang didapatkan dari internet, kemudian hasil request pada server web dengan menggunakan Mozila Filefox, Google Chrome dan Internet Explorer. Hasil tersebut kemudian dianalisis komparasi dari implementasi metode enkripsi AES, white-space standar dan white-space modified pada HTML5.

Tabel 1. Data Artikel

\begin{tabular}{lc}
\hline Artikel Eksperimen & Jumlah Karakter \\
\hline Cara menghidupkan komputer dan laptop yang baik dan benar & 521 \\
Cara mengatasi laptop tidak mau hidup atau menyala & 307 \\
Pengertian SSD & 321 \\
Pengertian Mouse Komputer dan Fungsinya & 560 \\
Pengertian Keyboard dan Jenis-Jenisnya & 1246 \\
Jenis-jenis Monitor & 934 \\
Jenis Kabel USB & 671 \\
Pengertian Touchpad & 95 \\
Pengertian Processor dan Macam-Macam Processor & 1209 \\
Malam Lailatul Qodar & 546 \\
\hline
\end{tabular}


Vol 8 No. 1,2020

(C)2020 Ilmu Komputer Unila Publishing Network All Rights Reserved

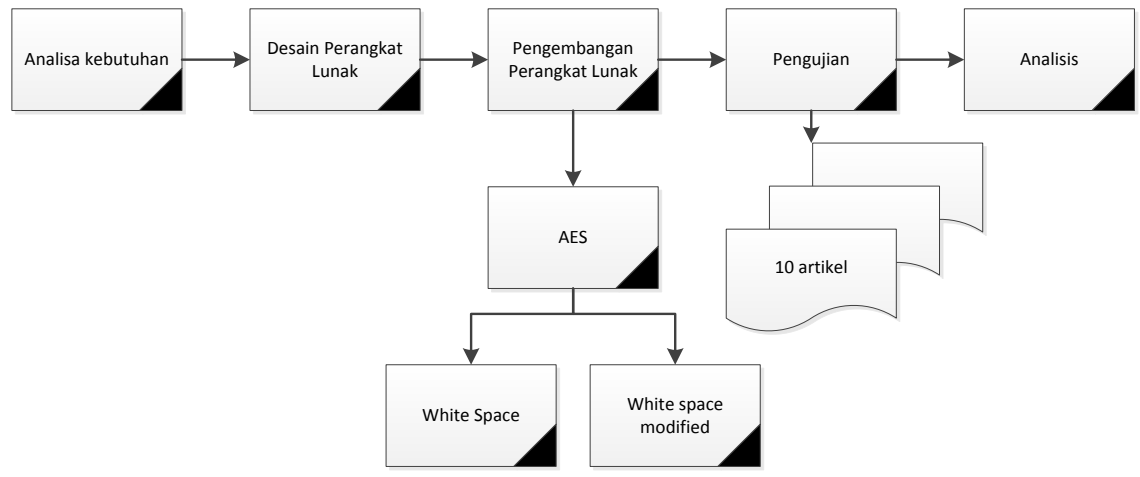

Gambar 1. Alur Penelitian

\section{[4] HASIL DAN PEMBAHASAN}

\subsection{Pengembangan Aplikasi}

Objek penelitian yang dibutuhkan pada penelitian ini adalah artikel.html yang nantinya akan diuji di perangkat lunak dengan enkripsi AES dan stegano white-space standar dan white-space modified. Maka dibuat perangkat lunak yang diperlukan dalam penelitian berbasis Web. Pembuatan perangkat lunak menggunakan bahasa php dan basis data yang digunakan adalah mysql, ditambah tools pembantu pembuatan web seperti XAMPP dan text editor.

Alur perangkat lunak pada proses enkripsi dan stegano sebagai berikut :

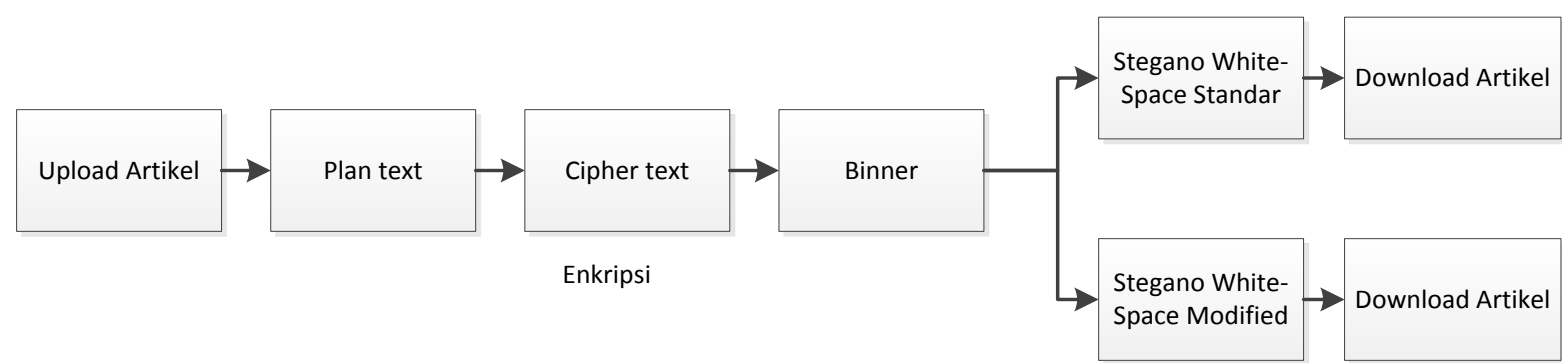

Gambar 2. Alur proses enkripsi dan stegano

Alur perangkat lunak pada proses destegano dan dekripsi sebagai berikut :

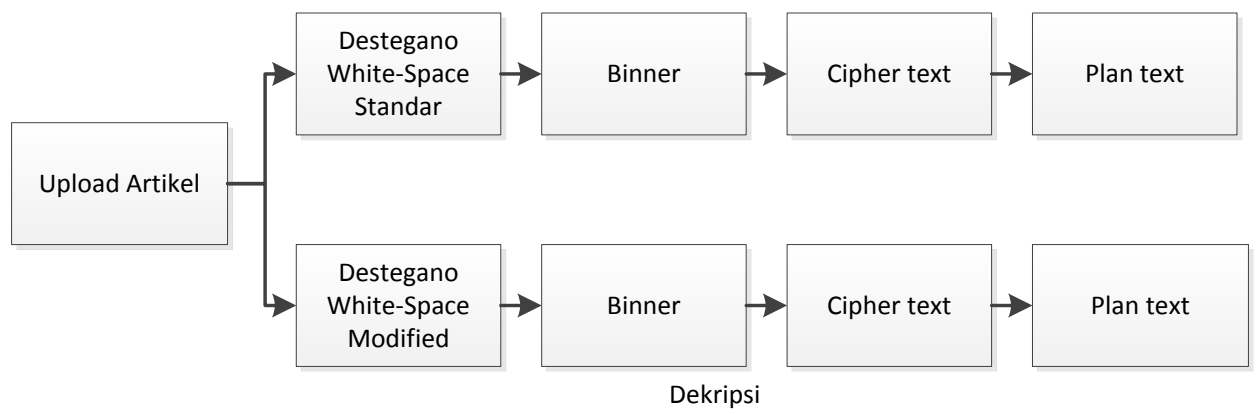

Gambar 3. Alur proses destegano dan deskripsi

Enkripsi AES dengan menggunakan library AES128, dengan source code sebagai berikut

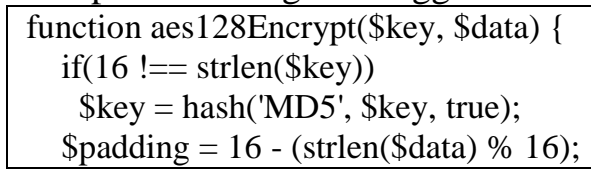




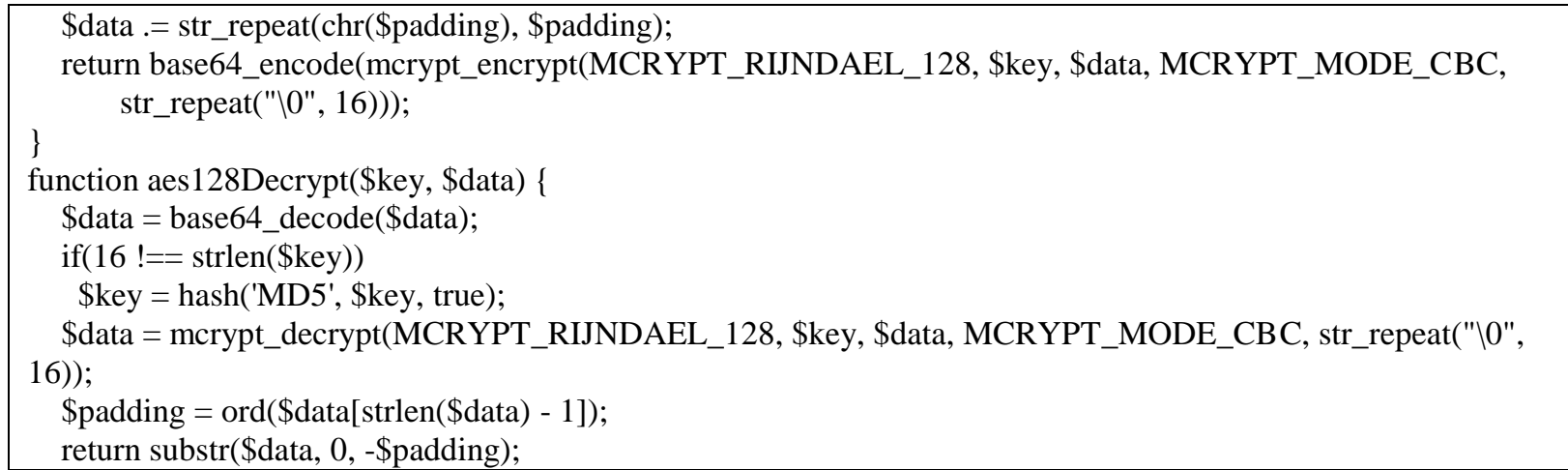

Pengubahan chippertext menjadi binner dan sebaliknya, dengan source code sebagai berikut

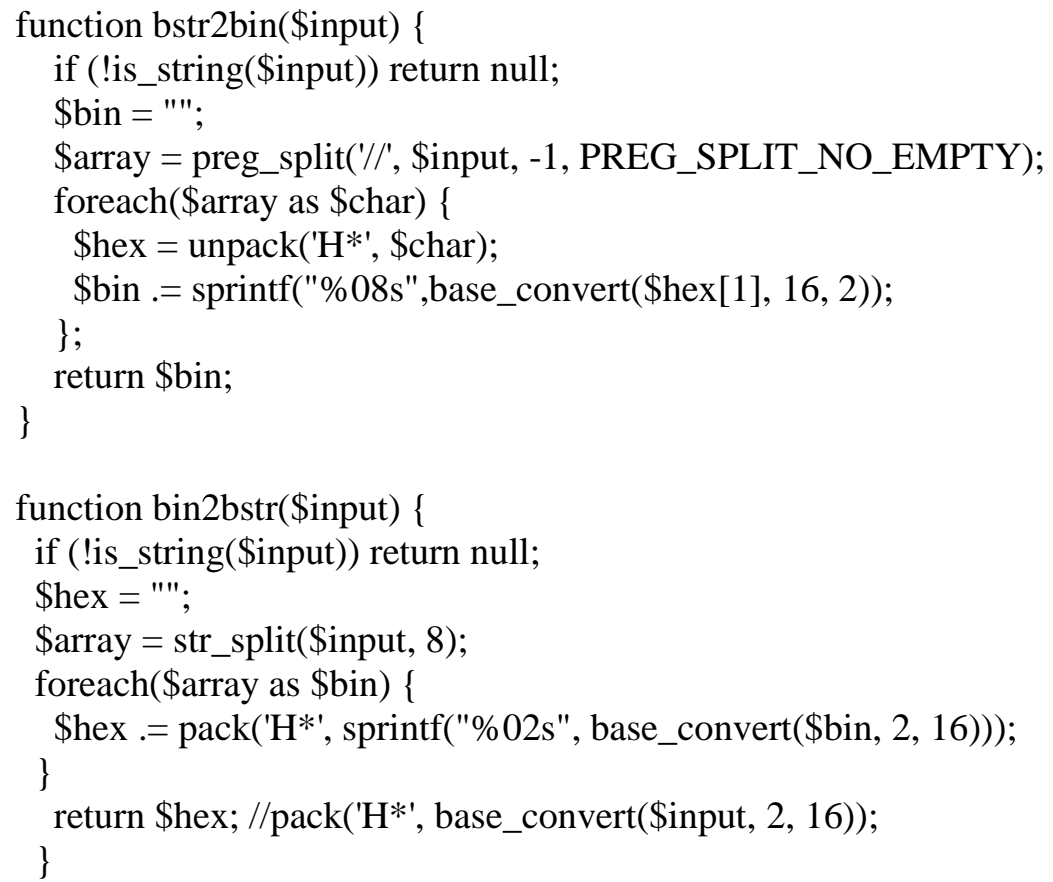

Proses stegano white-space standar, dengan source code sebagai berikut

foreach (\$split_cover_msg as \$row)\{

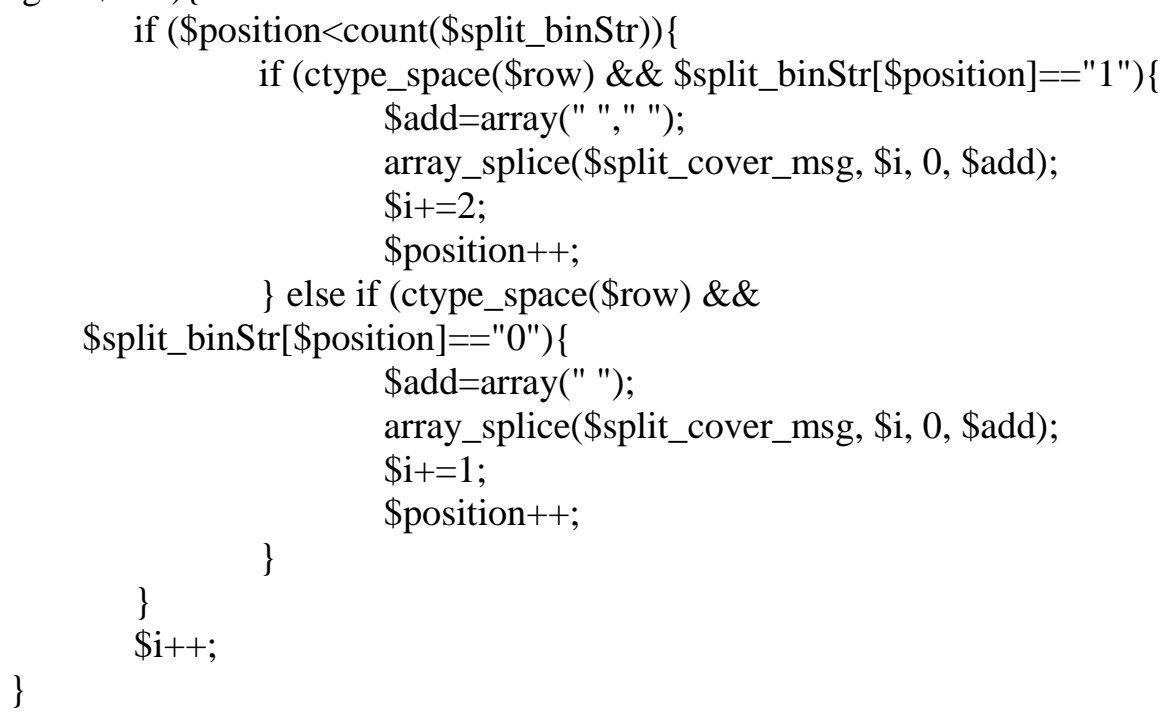


Proses destegano white-space standar, dengan source code sebagai berikut

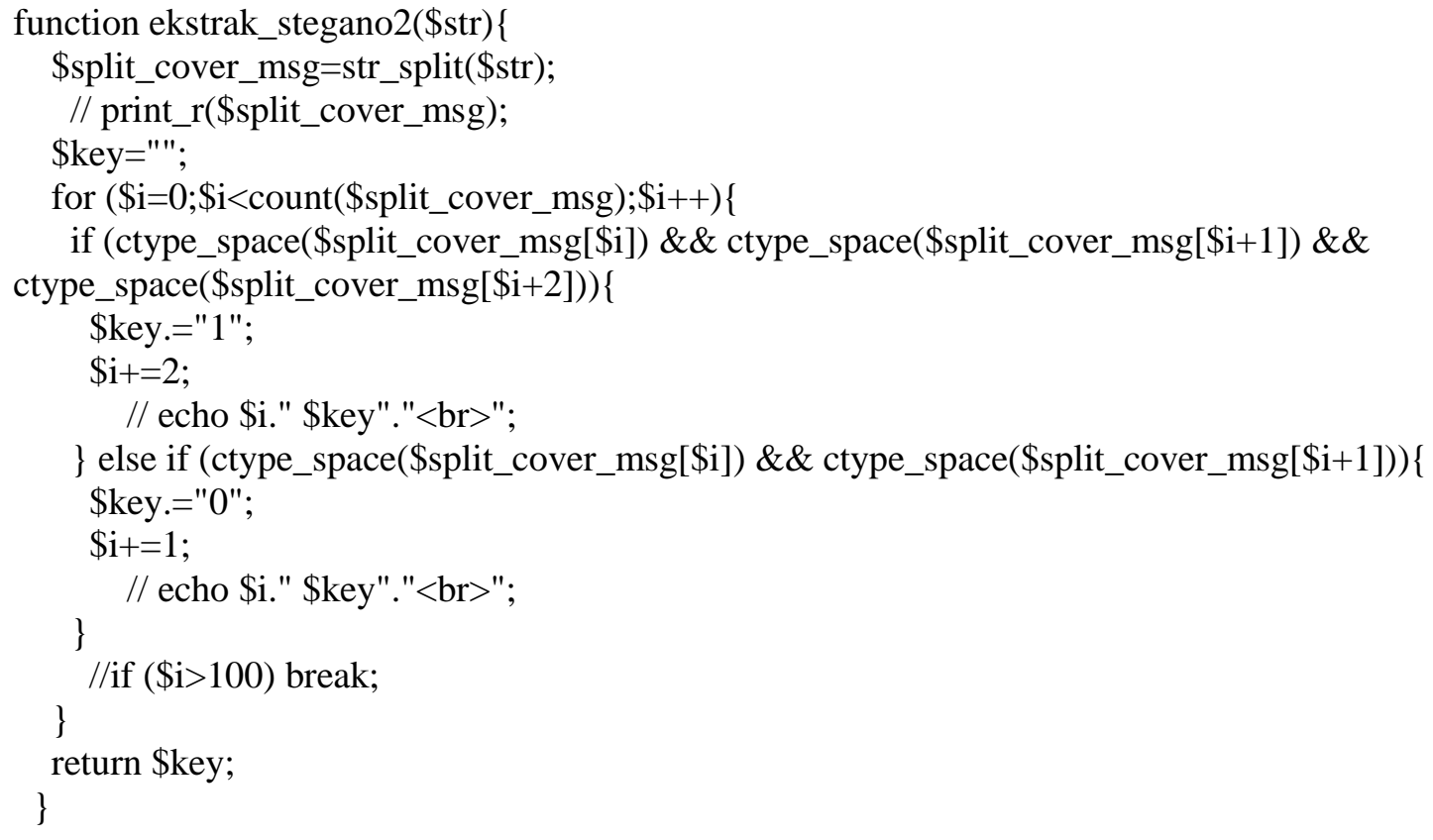

Proses stegano white-space modified, dengan source code sebagai berikut

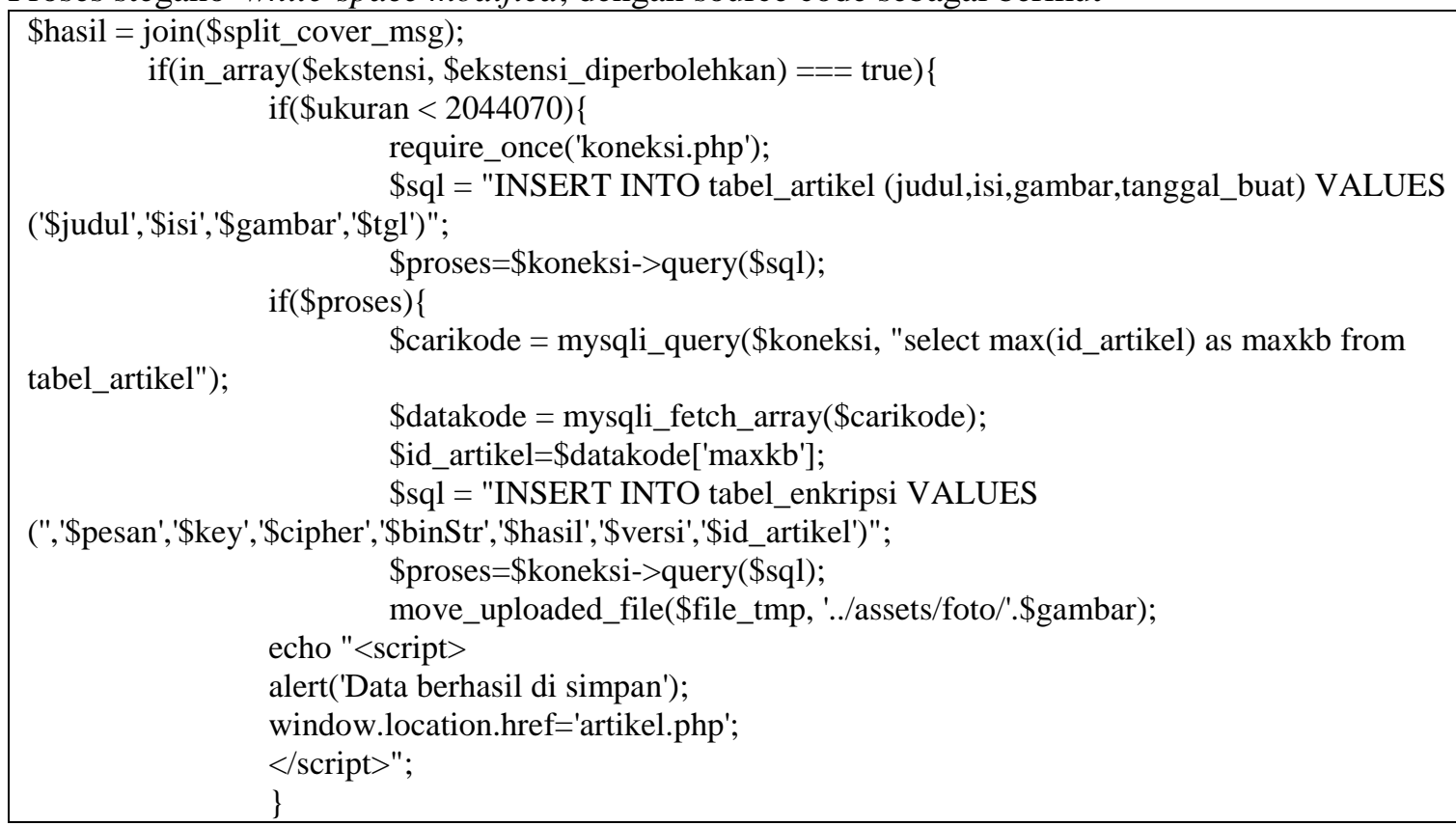

Proses destegano white-space modified, dengan source code sebagai berikut

function ekstrak_stegano2(\$str)\{

\$split_cover_msg=str_split(\$str);

\$key="";

for $(\$ \mathrm{i}=0 ; \$ \mathrm{i}<\mathrm{count}(\$$ split_cover_msg); $\$ \mathrm{i}++)\{$

if (ctype_space(\$split_cover_msg[\$i]) \&\& ctype_space(\$split_cover_msg[ $[i+1]) \& \&$

ctype_space $(\$$ split_cover_msg[ $[\$+2]))\{$

\$key.="1";

$\$ i+=2$;

\} else if (ctype_space(\$split_cover_msg[\$i]) \&\& ctype_space(\$split_cover_msg[\$i+1]))\{

\$key.="0"; 


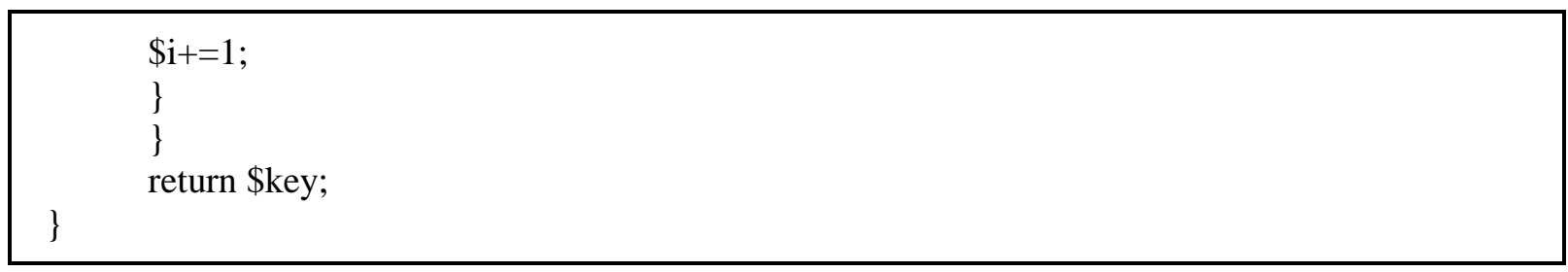

\subsection{Hasil Pengujian}

Pengujian dilakukan pada 3 browser berbeda yaitu Google Chrome, Mozila Firefox dan Internet Explorer. Artikel yang disisipkan pesan rahasia ada 10 artikel dengan 3 format enkripsi berbeda. Berikut tabel hasil yang telah diperoleh :

Tabel 2. Pengujian Google Crome

\begin{tabular}{|c|c|c|c|c|c|c|c|c|c|c|c|}
\hline \multirow{4}{*}{$\begin{array}{c}\text { Bany } \\
\text { ak } \\
\text { Kata } \\
\text { Pada } \\
\text { Artik } \\
\text { el }\end{array}$} & \multirow{4}{*}{$\begin{array}{c}\text { Judul } \\
\text { Artikel }\end{array}$} & \multirow{4}{*}{$\begin{array}{c}\text { Tidak } \\
\text { ada } \\
\text { Enkri } \\
\text { psi } \\
\text { Size } \\
\text { (bytes } \\
\text { ) }\end{array}$} & \multicolumn{8}{|c|}{ Ada Enkripsi } & \multirow[t]{4}{*}{ Key } \\
\hline & & & \multicolumn{2}{|c|}{ Enkrip } & Dek & \multicolumn{2}{|c|}{ Enkrip } & Dek & \multicolumn{2}{|c|}{ Dekrip } & \\
\hline & & & ver & $1+6 c r-s$ & $+7)$ & ver & $2(+1 d$ & $+2)$ & $\mathrm{Mod}$ & jied & \\
\hline & & & $\begin{array}{c}\text { Stat } \\
\text { us }\end{array}$ & $\begin{array}{l}\text { Size } \\
\text { (byte } \\
\text { s) }\end{array}$ & $\begin{array}{c}\text { Stat } \\
\text { us }\end{array}$ & $\begin{array}{c}\text { Stat } \\
\text { us }\end{array}$ & $\begin{array}{l}\text { Size } \\
\text { (byte } \\
\text { s) }\end{array}$ & $\begin{array}{l}\text { Stat } \\
\text { us }\end{array}$ & $\begin{array}{l}\text { Size } \\
\text { (byte } \\
\text { s) }\end{array}$ & $\begin{array}{c}\text { Stat } \\
\text { us }\end{array}$ & \\
\hline 521 & $\begin{array}{l}\text { 1GC Cara } \\
\text { menghidup } \\
\text { kan } \\
\text { komputer } \\
\text { dan laptop } \\
\text { yang baik } \\
\text { dan benar }\end{array}$ & $\begin{array}{c}331.7 \\
76\end{array}$ & $\begin{array}{c}\text { Suk } \\
\text { ses }\end{array}$ & $\begin{array}{l}333 . \\
312\end{array}$ & $\begin{array}{l}\text { Suk } \\
\text { ses } \\
\text { BT }\end{array}$ & $\begin{array}{l}\text { Suk } \\
\text { ses }\end{array}$ & $\begin{array}{c}332.2 \\
88\end{array}$ & $\begin{array}{l}\text { Suk } \\
\text { ses } \\
\text { BT }\end{array}$ & $\begin{array}{c}332.2 \\
88\end{array}$ & $\begin{array}{l}\text { Suk } \\
\text { ses }\end{array}$ & 1 \\
\hline 307 & $\begin{array}{l}\text { 2GC Cara } \\
\text { mengatasi } \\
\text { laptop } \\
\text { tidak mau } \\
\text { hidup atau } \\
\text { menyala }\end{array}$ & $\begin{array}{c}368.1 \\
28\end{array}$ & $\begin{array}{c}\text { Suk } \\
\text { ses }\end{array}$ & $\begin{array}{l}369 . \\
664\end{array}$ & $\begin{array}{c}\text { Gag } \\
\text { al }\end{array}$ & $\begin{array}{l}\text { Suk } \\
\text { ses }\end{array}$ & $\begin{array}{c}368.6 \\
40\end{array}$ & $\begin{array}{c}\text { Gag } \\
\text { al }\end{array}$ & $\begin{array}{c}368.6 \\
40\end{array}$ & $\begin{array}{l}\text { Suk } \\
\text { ses }\end{array}$ & 12 \\
\hline 321 & $\begin{array}{l}3 \mathrm{GC} \\
\text { Pengertian } \\
\text { SSD }\end{array}$ & $\begin{array}{c}323.5 \\
84\end{array}$ & $\begin{array}{c}\text { Suk } \\
\text { ses }\end{array}$ & $\begin{array}{l}324 . \\
608\end{array}$ & $\begin{array}{l}\text { Suk } \\
\text { ses } \\
\text { BT }\end{array}$ & $\begin{array}{c}\text { Suk } \\
\text { ses }\end{array}$ & $\begin{array}{c}324.0 \\
96\end{array}$ & $\begin{array}{l}\text { Suk } \\
\text { ses } \\
\text { BT }\end{array}$ & $\begin{array}{c}324.0 \\
96\end{array}$ & $\begin{array}{l}\text { Suk } \\
\text { ses }\end{array}$ & 123 \\
\hline 560 & $\begin{array}{l}4 \mathrm{GC} \\
\text { Pengertian } \\
\text { Mouse } \\
\text { Komputer } \\
\text { dan } \\
\text { Fungsinya }\end{array}$ & $\begin{array}{c}391.1 \\
68\end{array}$ & $\begin{array}{c}\text { Suk } \\
\text { ses }\end{array}$ & $\begin{array}{l}392 . \\
192\end{array}$ & $\begin{array}{l}\text { Suk } \\
\text { ses } \\
\text { BT }\end{array}$ & $\begin{array}{c}\text { Suk } \\
\text { ses }\end{array}$ & $\begin{array}{c}391.6 \\
80\end{array}$ & $\begin{array}{l}\text { Suk } \\
\text { ses } \\
\text { BT }\end{array}$ & $\begin{array}{c}391.6 \\
80\end{array}$ & $\begin{array}{l}\text { Suk } \\
\text { ses }\end{array}$ & 1234 \\
\hline 1246 & $\begin{array}{l}5 \mathrm{GC} \\
\text { Pengertian } \\
\text { Keyboard } \\
\text { dan Jenis- } \\
\text { Jenisnya }\end{array}$ & $\begin{array}{c}340.4 \\
80\end{array}$ & $\begin{array}{c}\text { Suk } \\
\text { ses }\end{array}$ & $\begin{array}{l}341 . \\
504\end{array}$ & $\begin{array}{l}\text { Suk } \\
\text { ses } \\
\text { BT }\end{array}$ & $\begin{array}{c}\text { Suk } \\
\text { ses }\end{array}$ & $\begin{array}{c}340.4 \\
80\end{array}$ & $\begin{array}{l}\text { Suk } \\
\text { ses } \\
\text { BT }\end{array}$ & $\begin{array}{c}340.4 \\
80\end{array}$ & $\begin{array}{c}\text { Suk } \\
\text { ses }\end{array}$ & 12345 \\
\hline 934 & $\begin{array}{l}\text { 6GC Jenis- } \\
\text { jenis } \\
\text { Monitor }\end{array}$ & $\begin{array}{c}351.2 \\
32\end{array}$ & $\begin{array}{c}\text { Suk } \\
\text { ses }\end{array}$ & $\begin{array}{l}352 . \\
256\end{array}$ & $\begin{array}{l}\text { Suk } \\
\text { ses } \\
\text { BT }\end{array}$ & $\begin{array}{l}\text { Suk } \\
\text { ses }\end{array}$ & $\begin{array}{c}351.7 \\
44\end{array}$ & $\begin{array}{l}\text { Suk } \\
\text { ses } \\
\text { BT }\end{array}$ & $\begin{array}{c}351.7 \\
44\end{array}$ & $\begin{array}{c}\text { Suk } \\
\text { ses }\end{array}$ & 123456 \\
\hline
\end{tabular}




\begin{tabular}{|c|c|c|c|c|c|c|c|c|c|c|c|}
\hline 671 & $\begin{array}{l}\text { 7GC Jenis } \\
\text { Kabel USB }\end{array}$ & $\begin{array}{c}337.4 \\
08\end{array}$ & $\begin{array}{l}\text { Suk } \\
\text { ses }\end{array}$ & $\begin{array}{l}338 . \\
432\end{array}$ & $\begin{array}{l}\text { Suk } \\
\text { ses } \\
\text { BT }\end{array}$ & $\begin{array}{l}\text { Suk } \\
\text { ses }\end{array}$ & $\begin{array}{c}337.9 \\
20\end{array}$ & $\begin{array}{l}\text { Suk } \\
\text { ses } \\
\text { BT }\end{array}$ & $\begin{array}{c}337.9 \\
20\end{array}$ & $\begin{array}{l}\text { Suk } \\
\text { ses }\end{array}$ & 1234567 \\
\hline 95 & $\begin{array}{l}8 \mathrm{GC} \\
\text { Pengertian } \\
\text { Touchpad }\end{array}$ & $\begin{array}{c}361.9 \\
84\end{array}$ & $\begin{array}{l}\text { Suk } \\
\text { ses }\end{array}$ & $\begin{array}{l}362 . \\
496\end{array}$ & $\begin{array}{c}\text { Gag } \\
\text { al }\end{array}$ & $\begin{array}{l}\text { Suk } \\
\text { ses }\end{array}$ & $\begin{array}{c}361.9 \\
84\end{array}$ & $\begin{array}{c}\text { Gag } \\
\text { al }\end{array}$ & $\begin{array}{c}361.9 \\
84\end{array}$ & $\begin{array}{c}\text { Gag } \\
\text { al }\end{array}$ & $\begin{array}{r}1234567 \\
8\end{array}$ \\
\hline 1209 & $\begin{array}{l}9 \text { GC } \\
\text { Pengertian } \\
\text { Processor } \\
\text { dan } \\
\text { Macam- } \\
\text { Macam } \\
\text { Processor }\end{array}$ & $\begin{array}{c}398.3 \\
36\end{array}$ & $\begin{array}{l}\text { Suk } \\
\text { ses }\end{array}$ & $\begin{array}{l}399 . \\
360\end{array}$ & $\begin{array}{l}\text { Suk } \\
\text { ses } \\
\text { BT }\end{array}$ & $\begin{array}{l}\text { Suk } \\
\text { ses }\end{array}$ & $\begin{array}{c}398.3 \\
36\end{array}$ & $\begin{array}{l}\text { Suk } \\
\text { ses } \\
\text { BT }\end{array}$ & $\begin{array}{c}398.3 \\
36\end{array}$ & $\begin{array}{l}\text { Suk } \\
\text { ses }\end{array}$ & $\begin{array}{r}1234567 \\
89\end{array}$ \\
\hline 546 & $\begin{array}{l}\text { 10GC } \\
\text { Malam } \\
\text { Lailatul } \\
\text { Qodar }\end{array}$ & $\begin{array}{c}327.1 \\
68\end{array}$ & $\begin{array}{l}\text { Suk } \\
\text { ses }\end{array}$ & $\begin{array}{l}328 . \\
192\end{array}$ & $\begin{array}{l}\text { Suk } \\
\text { ses } \\
\text { BT }\end{array}$ & $\begin{array}{l}\text { Suk } \\
\text { ses }\end{array}$ & $\begin{array}{c}327.1 \\
68\end{array}$ & $\begin{array}{l}\text { Suk } \\
\text { ses } \\
\text { BT }\end{array}$ & $\begin{array}{c}327.1 \\
68\end{array}$ & $\begin{array}{l}\text { Suk } \\
\text { ses }\end{array}$ & $\begin{array}{r}1234567 \\
890\end{array}$ \\
\hline
\end{tabular}

Tabel 3. Pengujian Pengujian Mozila Firefox

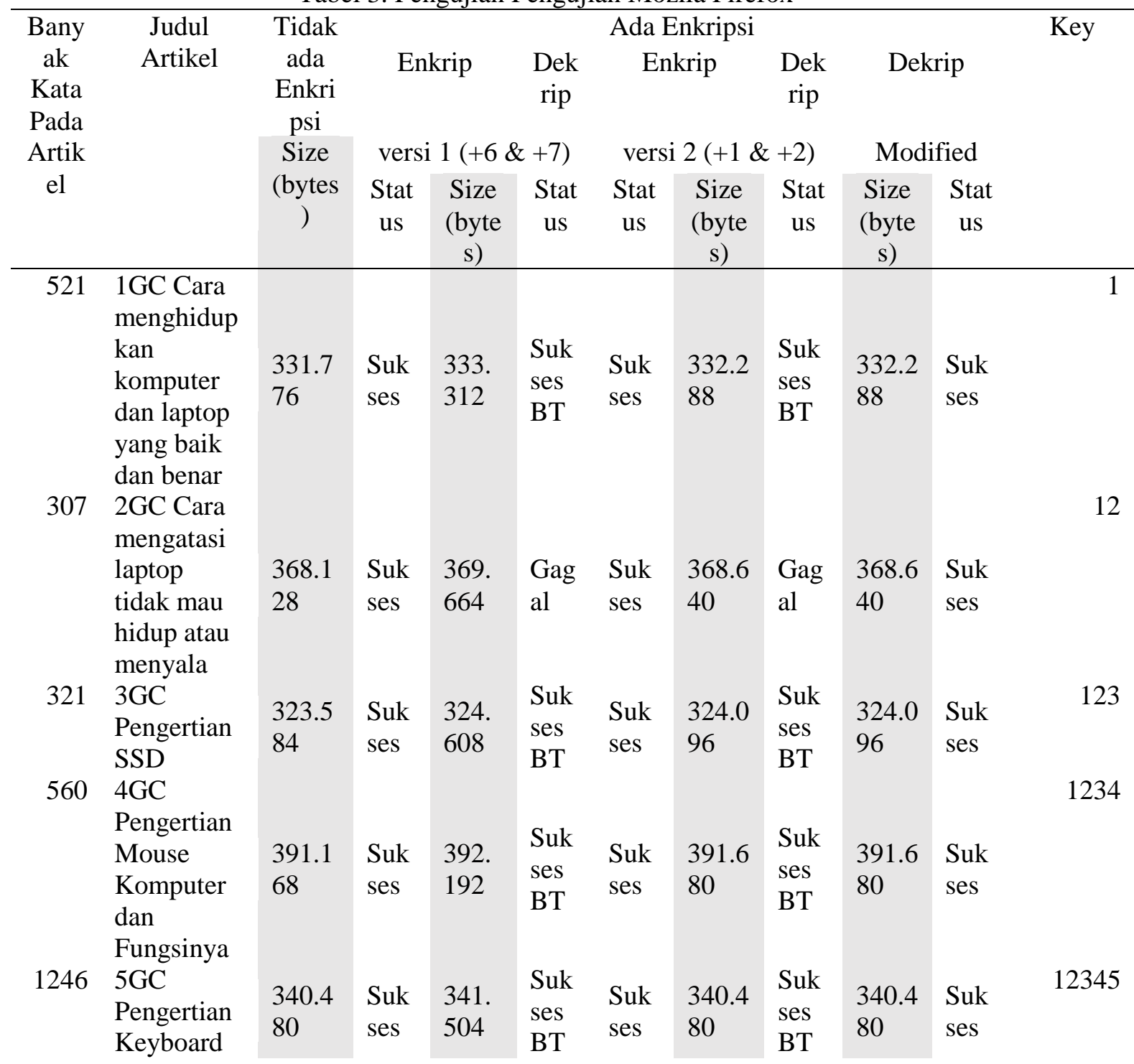


Vol 8 No. 1 , 2020

(C)2020 Ilmu Komputer Unila Publishing Network All Rights Reserved

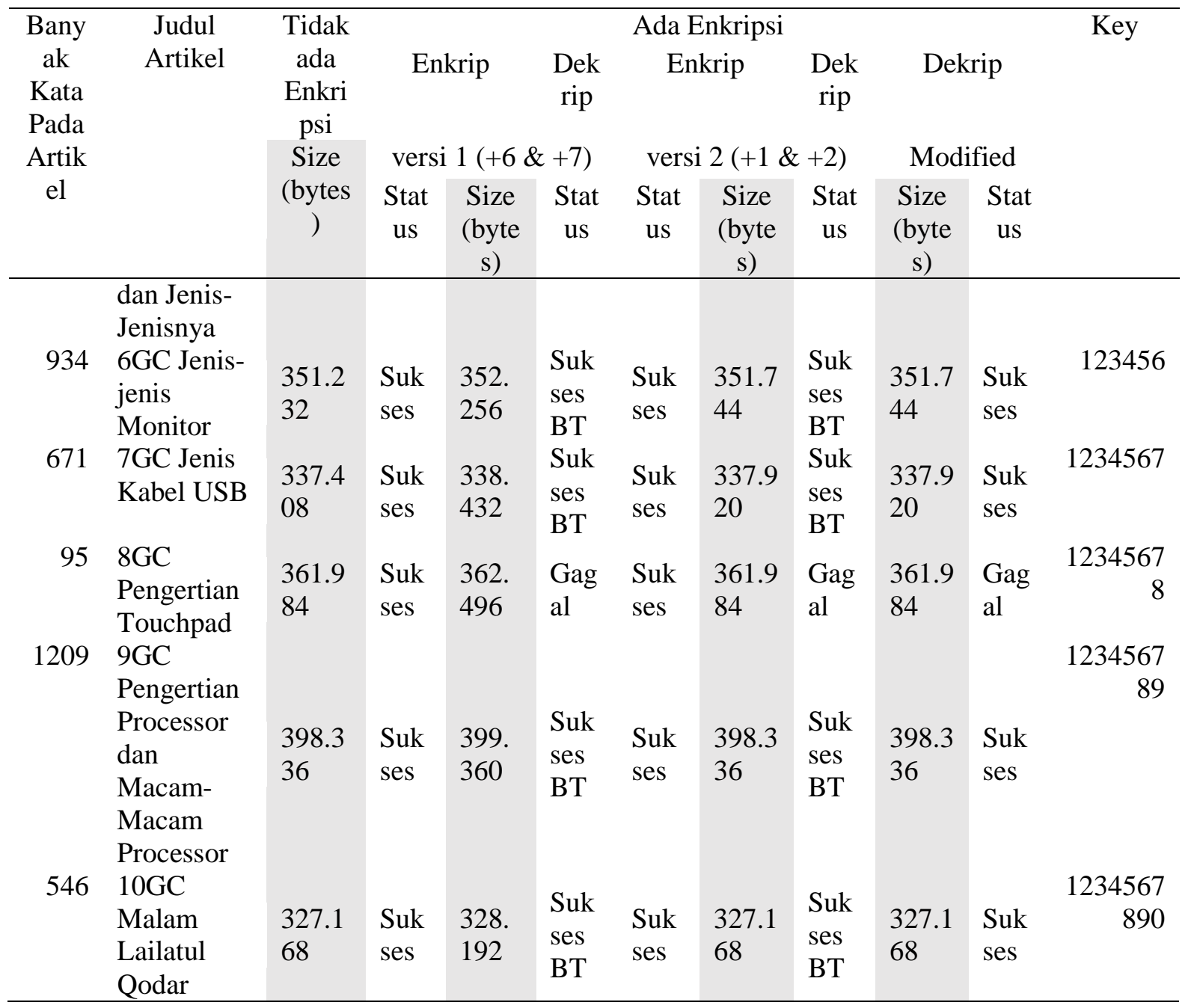

Tabel 4. Pengujian Internet Explorer

\begin{tabular}{|c|c|c|c|c|c|c|c|c|c|c|c|}
\hline \multirow{3}{*}{$\begin{array}{c}\text { Bany } \\
\text { ak } \\
\text { Kata } \\
\text { Pada } \\
\text { Artik } \\
\text { el }\end{array}$} & \multirow[t]{3}{*}{$\begin{array}{c}\text { Judul } \\
\text { Artikel }\end{array}$} & \multirow{3}{*}{$\begin{array}{c}\text { Tidak } \\
\text { ada } \\
\text { Enkri } \\
\text { psi } \\
\text { Size } \\
\text { (bytes } \\
\text { ) }\end{array}$} & \multicolumn{8}{|c|}{ Ada Enkripsi } & \multirow[t]{3}{*}{ Key } \\
\hline & & & vers & $1(+6$ & $+7)$ & ver: & $2(+1)$ & $+2)$ & Moc & fied & \\
\hline & & & $\begin{array}{c}\text { Stat } \\
\text { us }\end{array}$ & $\begin{array}{l}\text { Size } \\
\text { (byte } \\
\text { s) }\end{array}$ & $\begin{array}{c}\text { Stat } \\
\text { us }\end{array}$ & $\begin{array}{c}\text { Stat } \\
\text { us }\end{array}$ & $\begin{array}{l}\text { Size } \\
\text { (byte } \\
\text { s) }\end{array}$ & $\begin{array}{l}\text { Stat } \\
\text { us }\end{array}$ & $\begin{array}{c}\text { Size } \\
\text { (byte } \\
\text { s) }\end{array}$ & $\begin{array}{c}\text { Stat } \\
\text { us }\end{array}$ & \\
\hline 521 & $\begin{array}{l}\text { 1GC Cara } \\
\text { menghidup } \\
\text { kan } \\
\text { komputer } \\
\text { dan laptop } \\
\text { yang baik } \\
\text { dan benar }\end{array}$ & $\begin{array}{l}394.2 \\
40\end{array}$ & $\begin{array}{l}\text { Suk } \\
\text { ses }\end{array}$ & $\begin{array}{l}3957 \\
76\end{array}$ & $\begin{array}{l}\text { Suk } \\
\text { ses } \\
\text { BT }\end{array}$ & $\begin{array}{l}\text { Suk } \\
\text { ses }\end{array}$ & $\begin{array}{l}394.7 \\
52\end{array}$ & $\begin{array}{l}\text { Suk } \\
\text { ses } \\
\text { BT }\end{array}$ & $\begin{array}{l}394.7 \\
52\end{array}$ & $\begin{array}{l}\text { Suk } \\
\text { ses }\end{array}$ & 1 \\
\hline 307 & $\begin{array}{l}\text { 2GC Cara } \\
\text { mengatasi } \\
\text { laptop } \\
\text { tidak mau } \\
\text { hidup atau } \\
\text { menyala }\end{array}$ & $\begin{array}{l}430.5 \\
92\end{array}$ & $\begin{array}{l}\text { Suk } \\
\text { ses }\end{array}$ & $\begin{array}{l}432 . \\
128\end{array}$ & $\begin{array}{l}\text { Gag } \\
\text { al }\end{array}$ & $\begin{array}{l}\text { Suk } \\
\text { ses }\end{array}$ & $\begin{array}{l}431.1 \\
04\end{array}$ & $\begin{array}{l}\text { Gag } \\
\text { al }\end{array}$ & $\begin{array}{l}431.1 \\
04\end{array}$ & $\begin{array}{l}\text { Suk } \\
\text { ses }\end{array}$ & 12 \\
\hline
\end{tabular}


Vol 8 No. 1 , 2020

(C)2020 Ilmu Komputer Unila Publishing Network All Rights Reserved

\begin{tabular}{|c|c|c|c|c|c|c|c|c|c|c|c|}
\hline \multirow[t]{3}{*}{321} & \multirow{3}{*}{$\begin{array}{l}3 G C \\
\text { Pengertian } \\
\text { SSD }\end{array}$} & \multirow[b]{2}{*}{386.0} & \multirow[b]{2}{*}{ Suk } & \multirow[b]{2}{*}{387.} & Suk & & & Suk & & \multirow[b]{2}{*}{ Suk } & 123 \\
\hline & & & & & ses & Suk & 386.5 & ses & 386.5 & & \\
\hline & & & & & & & & BT & & & \\
\hline \multirow[t]{4}{*}{560} & $4 \mathrm{GC}$ & & & & & & & & & & 1234 \\
\hline & $\begin{array}{l}\text { Pengertian } \\
\text { Mouse }\end{array}$ & 453.6 & Suk & 455. & Suk & Suk & 454.1 & Suk & 4541 & Suk & \\
\hline & Komputer & 32 & ses & 168 & ses & $\begin{array}{l}\text { sun } \\
\text { ses }\end{array}$ & 44 & ses & 44 & ses & \\
\hline & dan & & & & & & & & & & \\
\hline \multirow[t]{3}{*}{1246} & $5 \mathrm{GC}$ & & & & & & & & & & 12345 \\
\hline & $\begin{array}{l}\text { Pengertian } \\
\text { Kevboard }\end{array}$ & 402.9 & Suk & 404. & $\begin{array}{l}\text { Suk } \\
\text { ses }\end{array}$ & Suk & 403.4 & $\begin{array}{l}\text { Suk } \\
\text { ses }\end{array}$ & 403.4 & Suk & \\
\hline & $\begin{array}{l}\text { dan Jenis- } \\
\text { Jenisnya }\end{array}$ & 44 & ses & 480 & BT & ses & 56 & BT & 56 & ses & \\
\hline \multirow[t]{2}{*}{934} & $\begin{array}{l}\text { 6GC Jenis- } \\
\text { jenis }\end{array}$ & 414.2 & Suk & 415. & Suk & Suk & 414.2 & Suk & 414.2 & Suk & 123456 \\
\hline & Monitor & 08 & ses & 232 & $\mathrm{BT}$ & ses & 08 & BT & 08 & ses & \\
\hline \multirow[t]{2}{*}{671} & 7GC Jenis & 399.8 & Suk & 401. & Suk & Suk & 400.3 & Suk & 400.3 & Suk & 1234567 \\
\hline & & 72 & ses & 408 & $\begin{array}{l}\text { ses } \\
\text { BT }\end{array}$ & ses & 84 & $\begin{array}{l}\text { ses } \\
\text { BT }\end{array}$ & 84 & ses & \\
\hline \multirow[t]{2}{*}{95} & $8 \mathrm{GC}$ & 424.4 & Suk & 424. & Gag & Suk & 424.4 & Gag & 424.4 & Suk & 1234567 \\
\hline & $\begin{array}{l}\text { Pengertian } \\
\text { Touchpad }\end{array}$ & 48 & ses & 960 & al & ses & 48 & al & 48 & ses & \\
\hline \multirow[t]{5}{*}{1209} & $9 \mathrm{GC}$ & & & & & & & & & & 1234567 \\
\hline & Pengertian & & & & & & & & & & 89 \\
\hline & $\begin{array}{l}\text { Processor } \\
\text { dan }\end{array}$ & 460.8 & Suk & 462. & $\begin{array}{l}\text { Suk } \\
\text { ses }\end{array}$ & Suk & 461.3 & $\begin{array}{l}\text { Suk } \\
\text { ses }\end{array}$ & 461.3 & Suk & \\
\hline & $\begin{array}{l}\text { Macam- } \\
\text { Macam }\end{array}$ & & & & BT & & & BT & 12 & ses & \\
\hline & Processor & & & & & & & & & & \\
\hline \multirow[t]{3}{*}{546} & 10GC & & & & Suk & & & Suk & & & 1234567 \\
\hline & Maiam & $\begin{array}{l}389.6 \\
32\end{array}$ & Suk & 391. & ses & Suk & 390.1 & ses & 390.1 & Suk & \\
\hline & Qodar & & & & BT & & & BT & & & \\
\hline
\end{tabular}

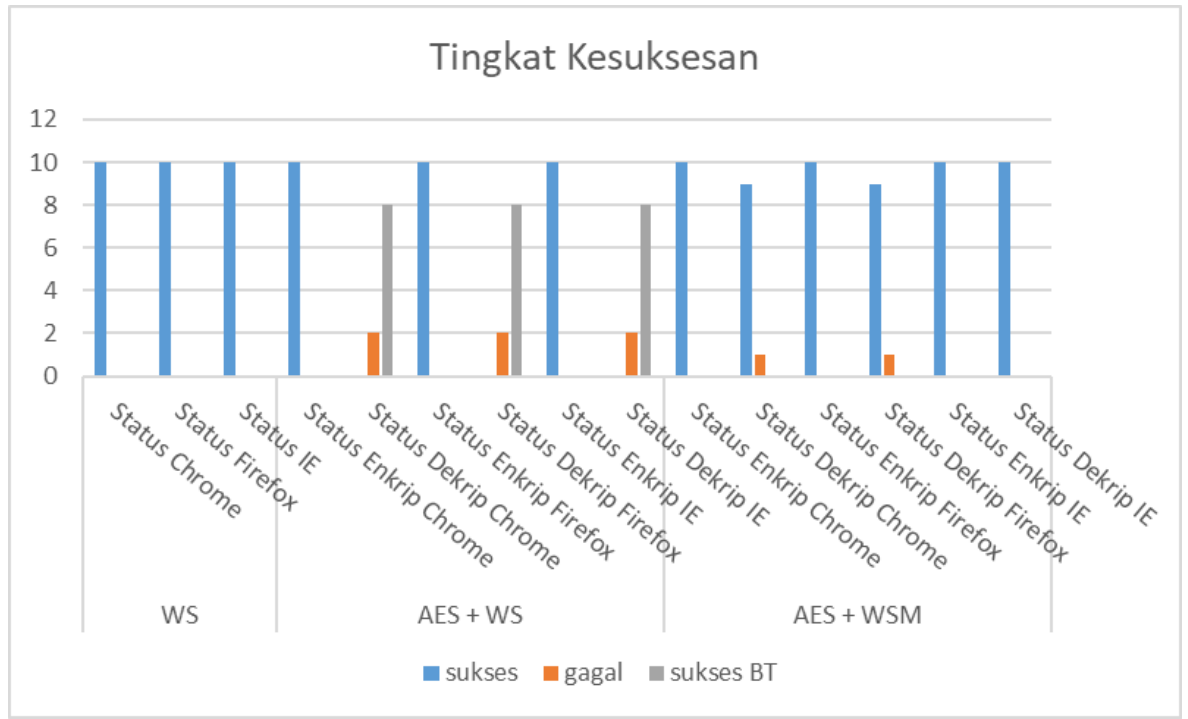

Gambar 4. Grafik Perbandingan keberhasilan 
Berdasarkan gambar 2, bahwa adanya tingkat keberhasil dalam melakukan enkripsi dan dekripsi dengan steganografi white-space. Pada penggunaan steganografi white-space standar, tanpa adanya enkripsi AES, proses penyisipan berhasil secara keseluruhan pada semua browser. Kemudian steganografi whitespace ini diimplementasikan dengan menggunakan enskripsi AES, menghasilkan proses enkripsi pada semua browser berhasil, tetapi pada proses dekripsi berhasil tetapi terjadi penambahan biner dengan karakter tidak dikenali.

Tetapi dengan implementasi white-space modified, hasil enkripsi berhasil dan hasil dekripsi berhasil 90\% keatas, tanpa ada terjadi penambahan biner. Pada browser Internet Explorer, seluruh proses berhasil dilakukan baik enkripsi maupun dekripsi pada seluruh artikel.

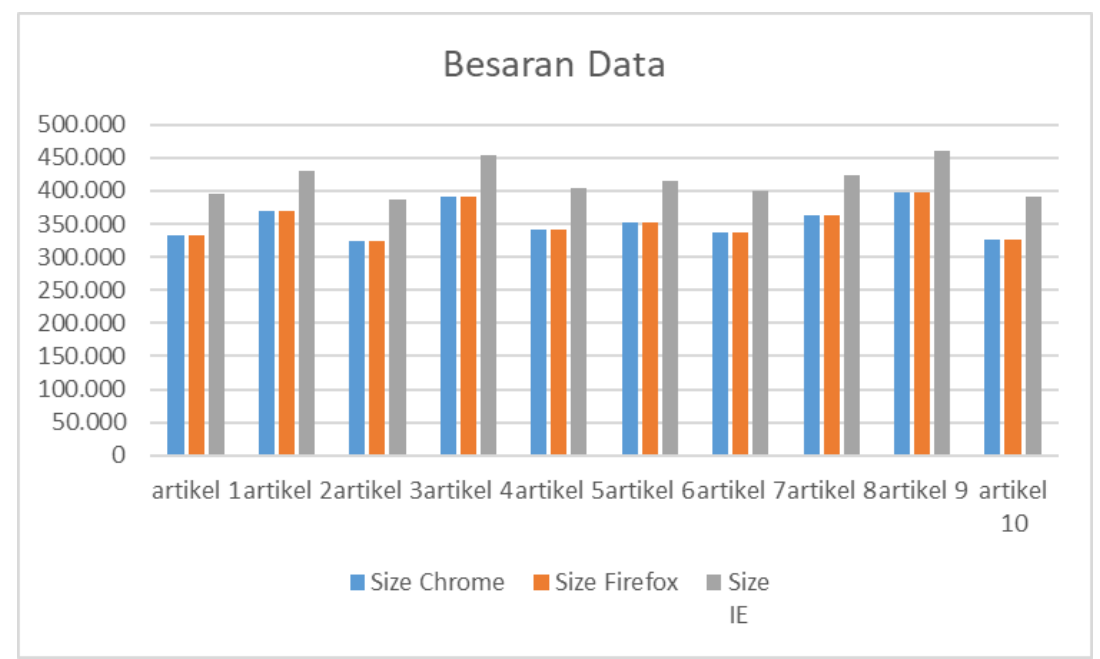

Gambar 5. Grafik Perbandingan besar data

Pada Internet Explorer menghasilkan ukuran data yang lebih besar di bandingkan dengan dua web browser sebelumnya. Hal ini disebabkan karena hasil request dari server menggunakan tahapan yang berbeda, dan ini berbanding terbalik dengan keberhasilan Internet Explorer dalam memproses enkripsi AES dan steganografi white-space modified.

Penggunaan Web browser tidak berpengaruh pada Steganografi metode white space modified. Persentase ukuran file yang dihasilkan antara browser Chrome dan Mozilla Firefox 100\% sama. Pada Internet Explorer saja persentase ukuran filenya yang berbeda, ukuran file yang dihasilkan lebih besar dibandingkan browser chrome dan mozilla.

\section{[5] KESIMPULAN}

Berdasarkan hasil penelitian maka diperoleh kesimpulan dari hasil pembahasan sebagai berikut:

a. Bahwa penggunaan AES dan white-space standar, keberhasilan hanya $80 \%$, dan juga terjadi tambahan biner yang menghasilkan karakter tidak dikenal. Sedangkan penggunaan white-space modified dapat meningkatkan keberhasilan penggunaan enkripsi AES pada HTML5. Browser Internet Explorer memiliki keberhasilan 100\%, walaupun Chrome dan Mozilla Firefox masih berhasil hingga 90\%. Hal ini terjadi karena pengaruh tabulasi ruang kosong yang banyak digunakan pada artikel dari internet.

b. Perubahan data yang terjadi setelah dilakukan perbandingan antara data yang terenkripsi dengan yang tidak ada enkripsi. Persentase perubahan data sangat kecil kurang dari satu persen bahkan mencapai kurang dari setengah persen. Sedangkan besaran file data penggunaan enkripsi AES dengan white-space dan whitespace modified memperlihatkan adanya perubahan besaran data terbesar yaitu pada browser Internet Explorer, sedangkan Google Chrome dan Mozila Firefox sama persis.

\section{DAFTAR PUSTAKA}


[1] Stanimir Zhelezov S., Uzunova B., Paraskevov D. H., 2017. An Approach For Hiding Steganography Data Within Web Applications. Faculty of Mathematics and Computer Science, Shumen University, 115, Universitetska St, 9700 Shumen, Bulgaria.

[2] Afif, Muhammad S. 2019. Analisis Implementasi Steganografi Modified White Space pada Data Terenkripsi AES untuk Menyembunyikan Pesan dalam HTML. Skripsi Program Studi Ilmu Komputer, Universitas Lambung Mangkurat, Banjarbaru.

[3] Usman, Nurdin. 2002. Konteks Implementasi Berbasis Kurikulum. PT. Raja Grafindo Persada. Jakarta. Indonesia.

[4] Khan F. R. \& Sher M. 2012. Innocuous Communication via HTML Hiding Data in Plain Sight. King Fahd University of Petroleum and Minerals. Arab Saudi.

[5] Cox, Ingemar J,(2008), "Digital Watermarking and Steganography Second Edition", Poytechnic University, Fox, Virginia.

[6] Mary S. R.M., \& Euphrasia K.R. 2016. Data Security Through Qr Code Encryption And Steganography. Dept. of Comp. Sci. and Applications, Gandhigram Rural Institute, Deemed University Gandhigram, TamilNadu. India.

[7] Odeh A, Khaled E., dkk. 2014. Novel Steganography over HTML. Department of Computer Science \& Engineering, University of Bridgeport. Bridgeport. USA.

[8] Prerna Mahajan P. \& Sachdeva A. 2013. A Study of Encryption Algorithms AES, DES and RSA for Security. Volume 13 Issue 15 Version 1.0. Global Journals Inc. USA.

[9] Suryana T, Amarullah A. 2004. Pengantar Internet dan HTML. Universitas Komputer Indonesia. Bandung. Indonesia.

[10]Herteno, R. (2019). Steganografi Untuk Pesan Terenkripsi Menggunakan Algoritma Kriptografi Rsa-Crt di Android. KLIK-KUMPULAN JURNAL ILMU KOMPUTER, 6, 16-26. doi: http://dx.doi.org/10.20527/klik.v6i1.246 